\title{
Asymmetric slip partitioning in the Sea of Marmara pull-apart: a clue to propagation processes of the North Anatolian Fault?
}

\author{
Rolando Armijo, ${ }^{1 *}$ Bertrand Meyer, ${ }^{1}$ Sébastien Navarro, ${ }^{1}$ Geoffrey King ${ }^{1}$ and Aykut Barka ${ }^{2}$ \\ ${ }^{1} I P G$, Paris (UMR. CNRS) 7578, Place Jussieu 4, Paris Cedex 75252,05, France; ${ }^{2}$ ITU, Eurasia Earth Sciences Institute, Ayazaga, 80626 \\ Istanbul, Turkey
}

\begin{abstract}
Between 1939 and 1999 the North Anatolian fault (NAF) experienced a westward progression of eight large earthquakes over $800 \mathrm{~km}$ of its morphological trace. The $2000-\mathrm{km}$-long North Anatolian transform fault has also grown by westward propagation through continental lithosphere over a much longer timescale ( $10 \mathrm{Myr})$. The Sea of Marmara is a large pull-apart that appears to have been a geometrical/mechanical obstacle encountered by the NAF during its propagation. The present paper focuses on new high-resolution data on the submarine fault system that forms a smaller pull-apart beneath the Northern Sea of Marmara, between two well-known strikeslip faults on land (Izmit and Ganos faults). The outstandingly clear submarine morphology reveals a segmented fault system including pull-apart features at a range of scales, which indicate a dominant transtensional tectonic regime. There is no evidence
\end{abstract}

\begin{abstract}
for a single, continuous, purely strike-slip fault. This result is critical to understanding of the seismic behaviour of this region of the NAF, close to Istanbul. Additionally, morphological and geological evidence is found for a stable kinematics consistent both with the long-term displacement field determined for the past $5 \mathrm{Myr}$ and with present-day Anatolia/Eurasia motion determined with GPS. However, within the Sea of Marmara region the fault kinematics involves asymmetric slip partitioning that appears to have extended throughout the evolution of the pull-apart. The loading associated with the westward propagation process of the NAF may have provided a favourable initial geometry for such a slip separation.
\end{abstract}

Terra Nova, 14, 80-86, 2002

\section{Introduction}

Unlike oceans with magnetic anomalies, active deformation of the continents is determined from the evolution of the morphology. Relief and other morphological features, such as offset river valleys, result from accumulation of displacement increments during repeated earthquakes (e.g. King et al., 1988; Stein et al., 1988; Yeats et al., 1997). A complete picture of an active region integrates morphological evidence with the geological evolution. In recent years this perspective has been applied to the study of the main faults of Turkey and Greece and, more specifically, to the North Anatolian fault (NAF). Both the morphological and the geological evidence require localized deformation and indicate a westward, plate-scale propagation of the NAF over the past $10 \mathrm{Myr}$ (Armijo et al., 1996,1999; HubertFerrari et al., 2002a). Such propagation appears mechanically similar to the process of rift propagation associated with continental break-up (Hubert-Ferrari et al., 2002b) and seems to involve long-term strength

*Correspondence: Rolando Armijo, IPG, Paris (UMR. CNRS) 7578, Place Jussieu 4, Paris Cedex 75252,05, France. Fax: + 33 144272440; e-mail: armijo@ipgp.jussieu.fr of the upper mantle. The Sea of Marmara pull-apart (Fig. 1) is an important structure on the NAF, but detailed study of this feature has only been possible previously from data on both sides of the pull-apart where the structure is well constrained. Offset geological markers across the main faults provide estimates of the total lateral displacement $(85 \mathrm{~km})$ and of slip rates over the past $5 \mathrm{Myr}$ since the NAF propagated across the area (Armijo et al., 1999). The occurrence of large earthquake ruptures [1912 Ganos earthquake (M 7.4) 1999 Izmit and Düzce earthquakes $\left(M_{\mathrm{w}} 7.4 ; 7.2\right)$, [Fig. 1] has provided examples of right-lateral slip increments corroborating the strike-slip morphology of the active faults on land. However, large earthquake ruptures are likely to occur within the next decades along the submarine faults beneath the Sea of Marmara (e.g. Hubert-Ferrari et al., 2000; Parsons et al., 2000). The new data comprise high-resolution bathymetry, seismic and sonar soundings, which enable the geometry of the main active faults of the Marmara Basin to be determined and the late Quaternary fault morphology and kinematics described. These kinematics are compared both with the larger scale displacement field obtained for the past $5 \mathrm{Myr}$ and with the present-day motion determined using GPS. This approach allows the degree of slip partitioning across the fault system to be determined and the possible mechanical evolution of the pull-apart to be discerned. It is of particular interest to assess whether the structure of the Sea of Marmara results chiefly from diffuse extensional deformation of the Aegean domain, or from localized lithospheric shear associated with the NAF.

\section{The Sea of Marmara pull-apart system}

In the Sea of Marmara region, the right-lateral NAF splays into two major fault branches that are about $100 \mathrm{~km}$ apart, before entering the Aegean westwards (Fig. 1, insert). According to available geological and geodetic data (Armijo et al., 1999; McClusky et al., 2000), most of the lateral motion appears to be transferred obliquely northward, from the main to the northern branch, across the large rhomb-shaped basin that the two branches embrace. Therefore, the Sea of Marmara is basically an extensional step-over, or pull-apart structure (Fig. 1). Such a configuration requires substantial subsidence and localized crustal stretching. 


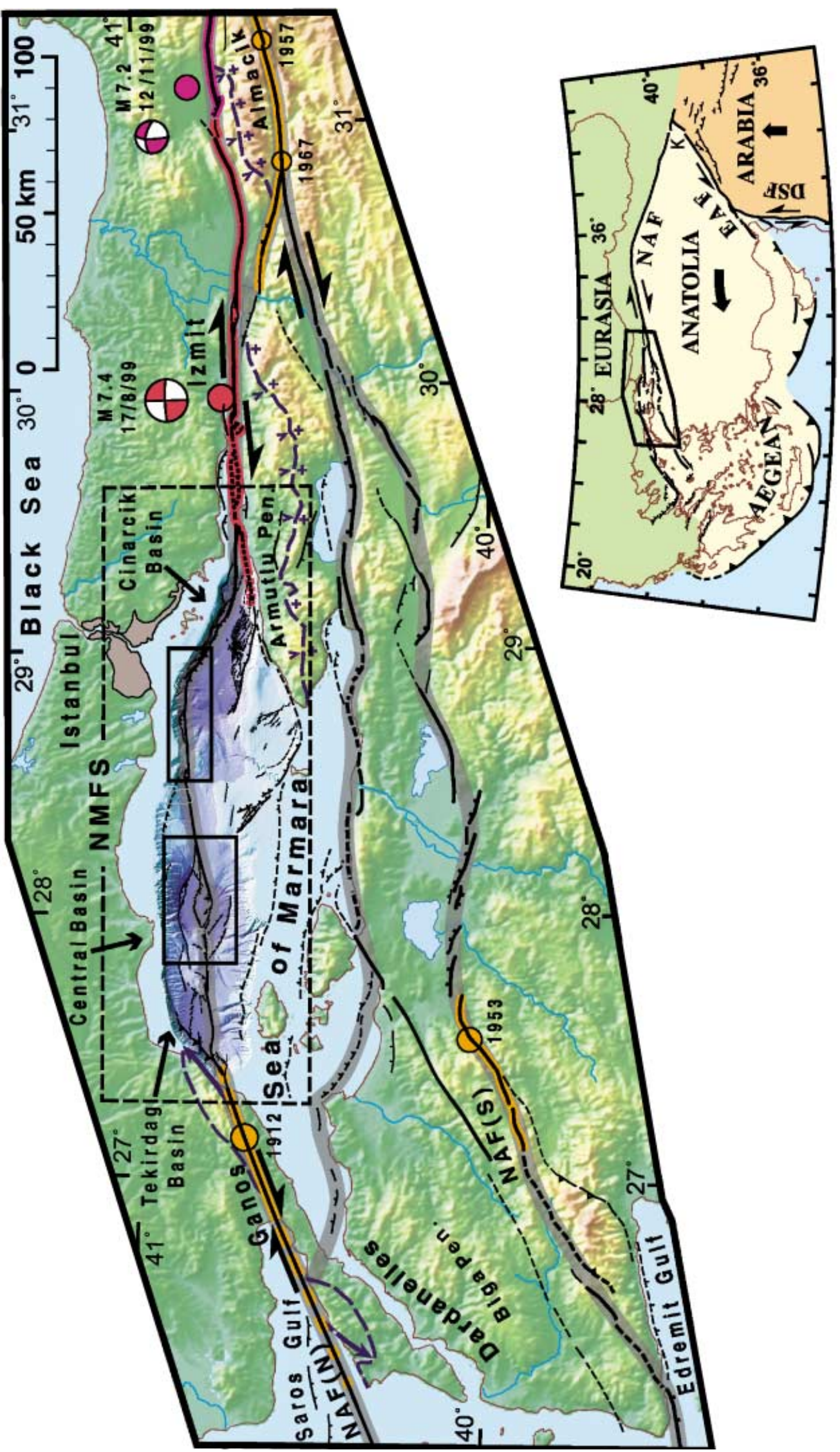

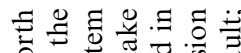

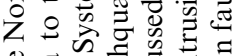

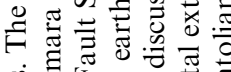

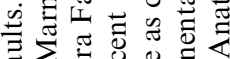

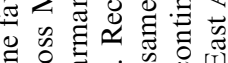

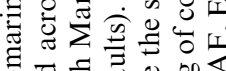

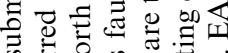

离

를 छ

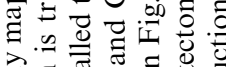

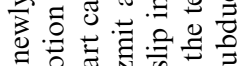

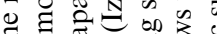

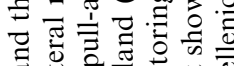

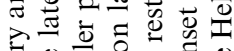

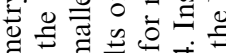

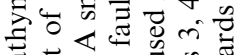

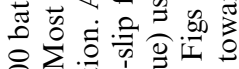

$8 \sum .0$

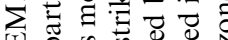

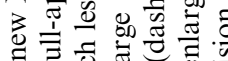

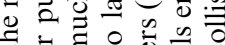

of

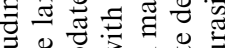

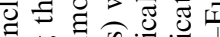

ส.

亏े

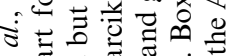

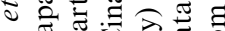

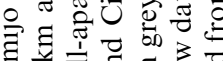

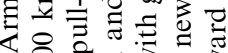

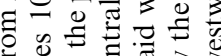

\pm क त 3

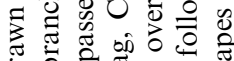

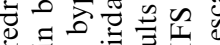

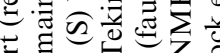

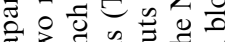

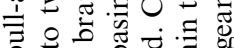

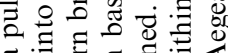

푸월

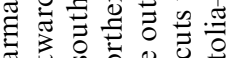

$\sum^{\pi} 000$

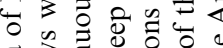

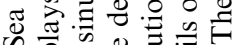

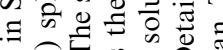

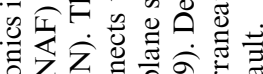

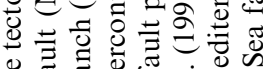

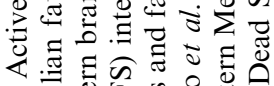

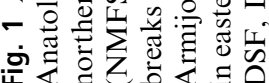


Accordingly, the Marmara basin contains significant amounts of recent sediment (average thickness 1-2 km), which is very thick in the deeper northern basins $(>6 \mathrm{~km})$ and is cut by large normal faults, as observed in seismic profiles (e.g. Parke et al., 1999). Within the larger Marmara pull-apart, a smaller pull-apart is formed by an oblique submarine fault zone which links the two strike-slip branches that ruptured in 1912 and 1999 (Ganos and Izmit faults). This oblique submarine zone is here termed the North Marmara Fault System (NMFS). Within the NMFS two shallower ridges at about 700-m depth separate an arrangement of three deep basins (with depths over $1000 \mathrm{~m}$; from east to west, Cinarcik, Central and Tekirdag basins). Several recent studies using seismic reflection profiles have proposed detailed maps of the submarine structure (e.g. Okay et al., 1999; 2000; Parke et al., 1999; Imren et al., 2001). Although the dataset is similar, each interpretation is different and it is difficult to explain the discrepancies. The present contribution uses high-resolution data on the NMFS collected during the French-Turkish cruise carried out aboard RV Suroit in September-October 2000. They include a EM-300 multibeam bathymetry map with $25 \mathrm{~m}$ gridding (Fig. 2), back-scatter and side-scan sonar imagery, and seismic reflection profiles using surface and deep-towed streamers. Le Pichon et al. (2001) recently presented these data, a fault map and a tectonic interpretation. The present contribution offers a discussion of the outstanding morphological features clearly exposed in two selected areas (Figs 3 and 4) and provides a tectonic interpretation consistent with our knowledge of the NAF elsewhere.

The morphology of the active faults is well preserved on the seafloor. Fault scarps probably resulting from many seismic events can be followed over tens of kilometres and described in detail. Individual breaks that may correspond to earthquakes in the recent past are also distinguishable. Most scarps show clear normal and strike-slip fault morphology, forming bends and pull-apart features at a range of scales. As anticipated (e.g. Barka and Kadinsky-Cade, 1988), active faulting along the NMFS is segmented and appears to interconnect the largest pull-apart basins (Cinarcik, Central and Tekirdag Basins) with the Izmit and Ganos faults on land (Fig. 1).

In the middle of the Central Basin (Fig. 3), distinct en echelon fault scarps enclose a pull-apart with a characteristic rhomb shape. The individual scarps strike NW-SE and display clear normal fault morphology across the most recent sediment. They are, on average, 1-2 km long and the flat floor of the pull-apart is $20-60 \mathrm{~m}$ deeper than the surrounding seafloor. Clear young fault scarps with similar strike also run at the base of the much larger - probably longer term escarpments located at the edges of the Central Basin. Both the inner and outer faults of the basin thus have normal components of slip and appear to splay, in map view, from linear right-lateral fault segments striking ENE-WSW, which are located east and west of the pull-apart structure. Between these two segments, the extensional step-over is about $4 \mathrm{~km}$. The nested graben structure that characterizes the geometry of the subsiding Central Basin in cross section is well portrayed in the seismic profiles (Fig. 3, lower panel). Indeed, nested pull-apart features are indicative of a long-lived geological structure in the Central Basin, controlled by a stable mechanism.

The underlying kinematics governing active faulting in the NMFS appear to be well determined at the sharp bend connecting two major fault segments with different strike, south of Istanbul (Figs 1 and 4). The fault seen west of the bend is a linear strike-slip fault striking $\mathrm{N} 80^{\circ} \mathrm{E}$ that crosses the shallower area separating the Central and Cinarcik basins. A ridge intersecting the fault is offset $3.5 \mathrm{~km}$ right-laterally. This feature provides us with an estimate of displacement on the NMFS over the past few $10^{5}$ years (see caption of Fig. 4). In contrast, the fault east of the bend is at the base of the large NW-SEstriking escarpment forming the northern edge of the Cinarcik Basin. An arrangement of en echelon normal fault scarps with throws of 60-100 m is seen along this fault. This suggests that composite normal and strikeslip during repeated earthquakes is responsible for the creation of the
Fig. 2 Bathymetric map of the North Marmara Fault System (NMFS) (contours in metres).

1000-m-high, 40-km-long, North Cinarcik escarpment. Interestingly, two parallel fault traces $1-2 \mathrm{~km}$ apart are observed over $10 \mathrm{~km}$ in the bend area, suggesting slip partitioning: almost purely right-lateral slip across the southern linear fault; significant normal slip across the fault at the base of the large escarpment. Similar features have been described elsewhere in basins under oblique extension (Armijo et al., 1986; Yeats et al., 1997).

Finally, some compressional structures can be deduced from the seafloor morphology and seismic profiles at the appropriate contractional bends and stepovers of the NMFS. These are minor features. Examples are found in the western half of the Sea of Marmara, over the two sides of the central pull-apart basin (Fig. 3). Thrusting seems particularly prominent at the Ganos bend, at the western end of the NMFS (Fig. 1), where active folding has been described on land (Armijo et al., 1999).

\section{Kinematic reconstruction, slip partitioning within the pull-apart}

The foregoing observations of the fault morphology and kinematics can be used to make a simple reconstruction of the NMFS such as that presented in Fig. 5(a). The motion is assumed to be localized on the larger submarine faults and the strike-slip segments identified on land. This stage of reconstruction incorporates neither deformation on smaller faults, nor slip on faults whose trace does not definitely link with the larger faults. Restoring the $3.5-\mathrm{km}$ right-lateral slip observed in the morphology (Fig. 5a) indicates where and how extensional (yellow) and compressional (pink) deformation should be accommodated and defines the motion across the NMFS over the past few $10^{5}$ years. These kinematics can be compared with independently determined, longer-term geological information and larger-scale kinematics.

The reconstruction of the overall Marmara pull-apart at $\approx 5 \mathrm{Ma}$ (Fig. 5b) is from Armijo et al. (1999) 


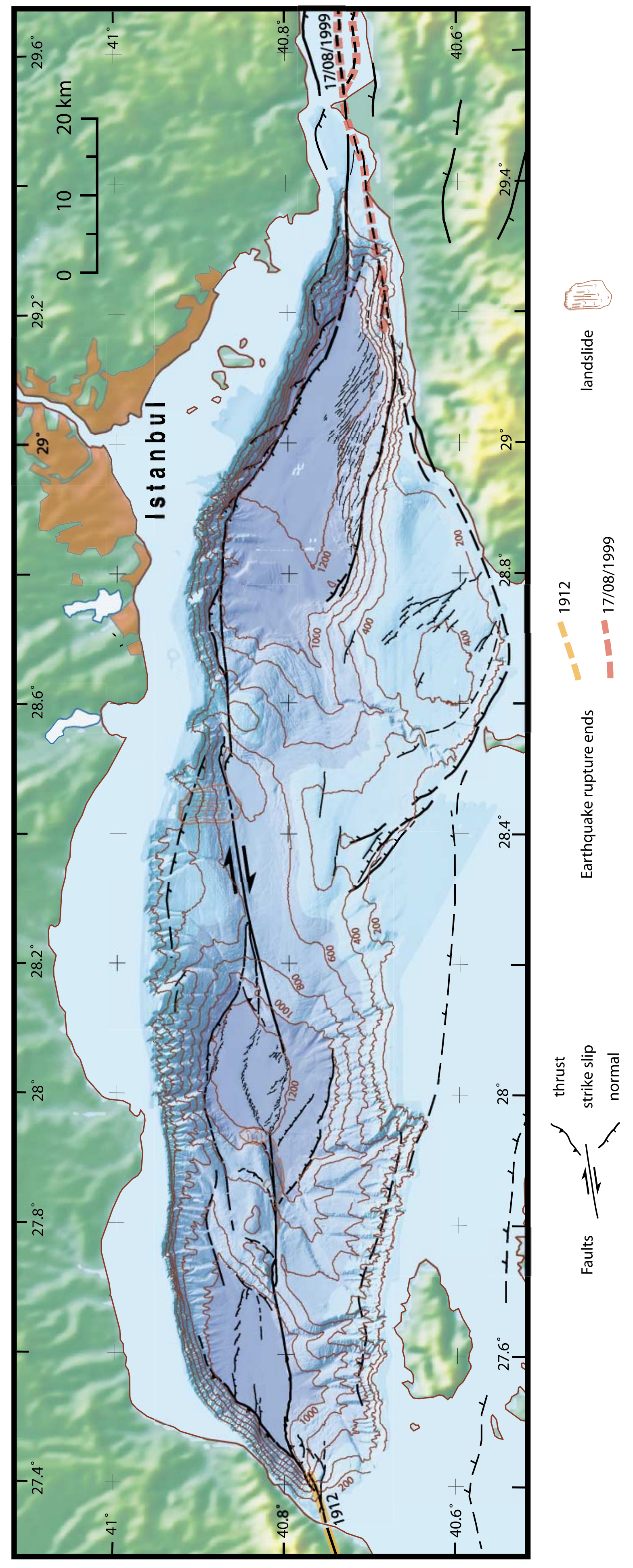




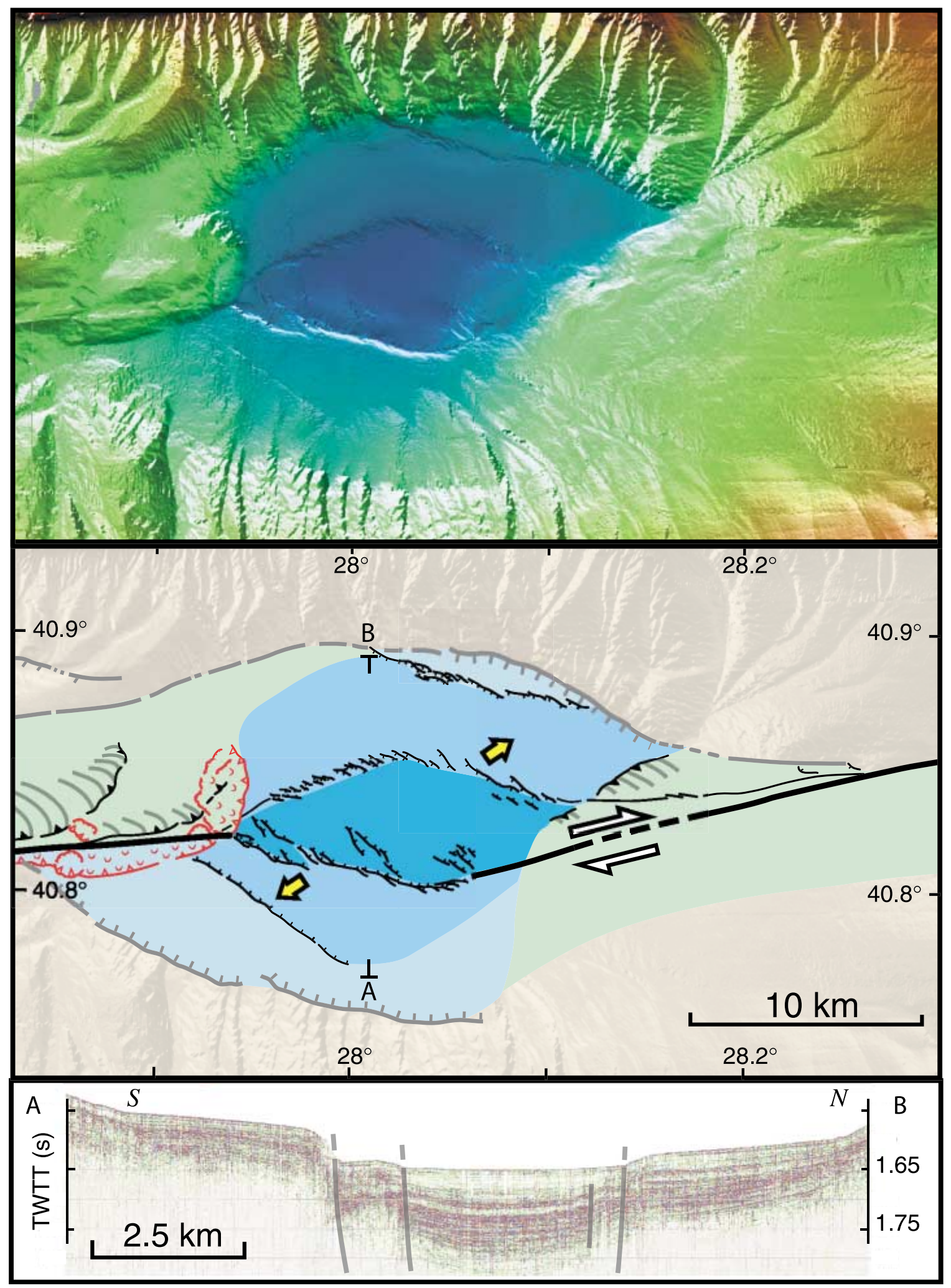

Fig. 3 Details of the Central Basin. An internal pull-apart has formed within the larger pull-apart structure. Outline (middle) shows en echelon normal faults and corresponding extension direction (yellow arrows). Subsidiary zones of compression (hatched) may exist on eastern and western sides of the pull-apart. Main strike-slip faults in bold. Slumped areas shown in red. Nested rift-inrift structure and young sediment fill are seen in the cross section (A-B; below, single-channel sparker profile). 


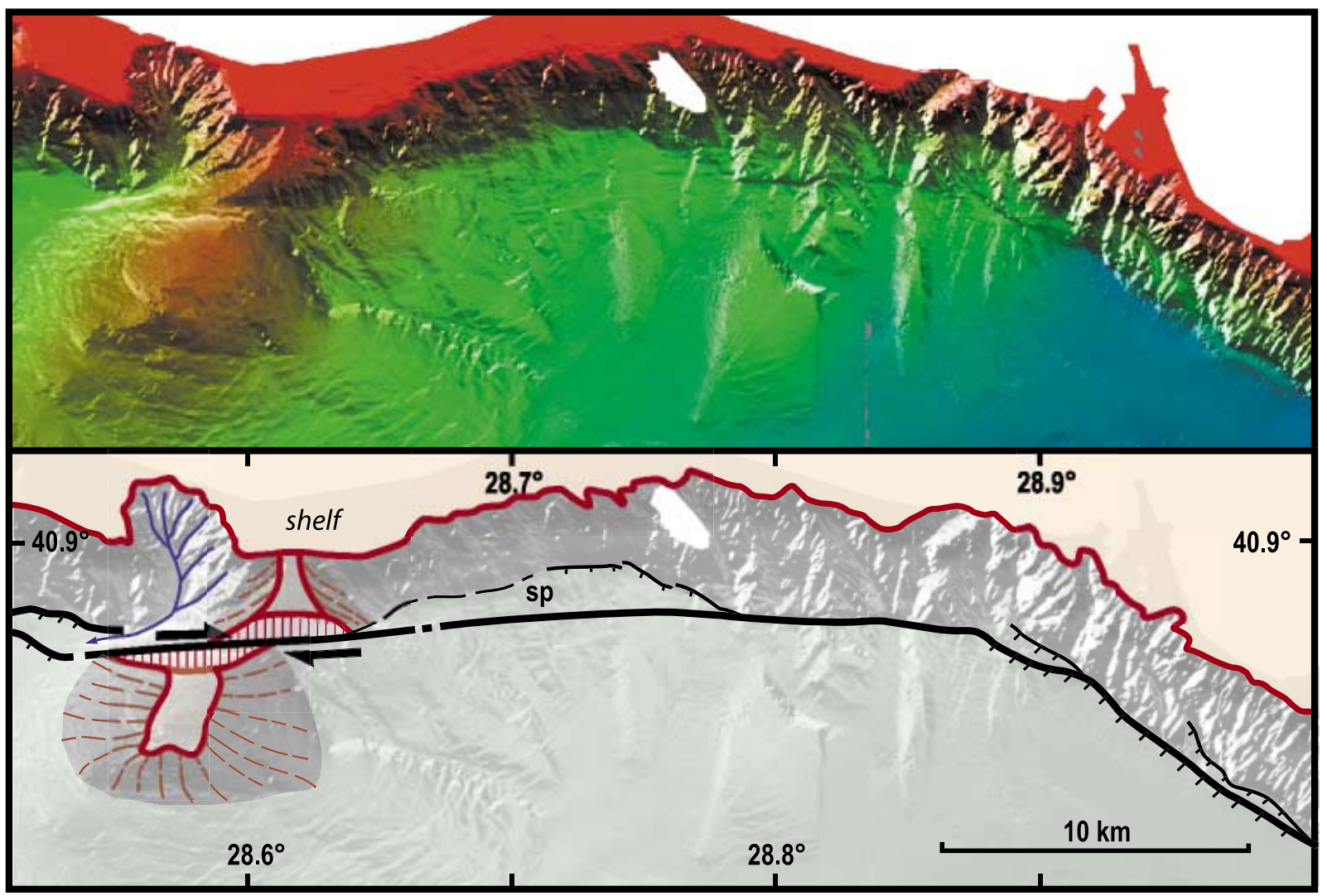

Fig. 4 Connection between normal and strike-slip faulting at the fault bend north-west of Cinarcik basin (south of Istanbul). Scarps 50-100 m high, striking NW at the base of the steep rough slopes of the 1000-m-high basin margin (to the NE) turn into a right-lateral WSW-striking fault (to the SW). Note the ridge that is laterally offset $3.5 \mathrm{~km}$ and the apparent slip partitioning at 'sp'. The morphological offset here is the clearest found in the bathymetry of the Sea of Marmara. Taking a possible slip-rate range of $1-2.5 \mathrm{~cm} \mathrm{yr}^{-1}$ (consistent with $50-100 \%$ of the rates derived from the geological observations and from the GPS measurements) gives possible offset ages of 1.4-3.5 $\times 10^{5} \mathrm{yr}$.

(slightly modified). The Anatolia-Eurasia direction of motion is the same as that determined with GPS (McClusky et al., 2000; purple arcs in Fig. 5a and b). The model restores the initial geometry of structural markers just prior to the NAF propagation through the Dardanelles region and involves $85 \mathrm{~km}$ total right-lateral displacement of Anatolia relative to Eurasia, most of it (70-90\%) accommodated across the Northern Branch. The displacement field obtained involves slip partitioning in the Sea of Marmara. Specifically, a larger proportion of strike-slip motion, relative to extension, appears to be accommodated NE of the pull-apart, across the NMFS. Conversely, a more extensional regime is expected across the shelf SW of the pull-apart, consistent with the dominant normal faulting observed in the seismic profiles (Parke et al., 2000). No difference can be resolved for the direction of motion determined across the NMFS in the two reconstructions shown in Fig. 5, despite the different timescales (see caption of Fig. 5b).

\section{Mechanical implications}

The North Marmara Fault System involves oblique extension and is segmented. This is inconsistent with the hypothesis of a single, throughgoing, purely strike-slip fault (Le Pichon et al., 2001). The NMFS includes significant fault step-overs that could arrest propagation of large seismic ruptures. Thus, the relatively complex geometry and kinematics of active faults along the NMFS appear consistent with the inference that destructive historical earthquakes have been generally smaller in the
Sea of Marmara than elsewhere along the NAF (Ambraseys and Jackson, 2000).

Motions over $10^{5} \mathrm{yr}$ and $5 \times 10^{6} \mathrm{yr}$ in the Sea of Marmara region are consistent with the broader kinematics of the extrusion of Anatolia derived from space geodesy (McClusky et al., 2000). Any overall opening attributable to Aegean extension (e.g. Sengör et al., 1985; Parke et al., 1999) is small and the extension that has created the Marmara basin results from the overall step-over formed with the northern branch of the NAF. The southern branch of the NAF takes up some right-lateral motion, but this is no more than $20 \%$ of the total. Within the Marmara pull-apart, block motion describes the kinematics with one block boundary (the NMFS) carrying a greater ratio of strike-slip to normal motion than others. The same asym- 
(a)
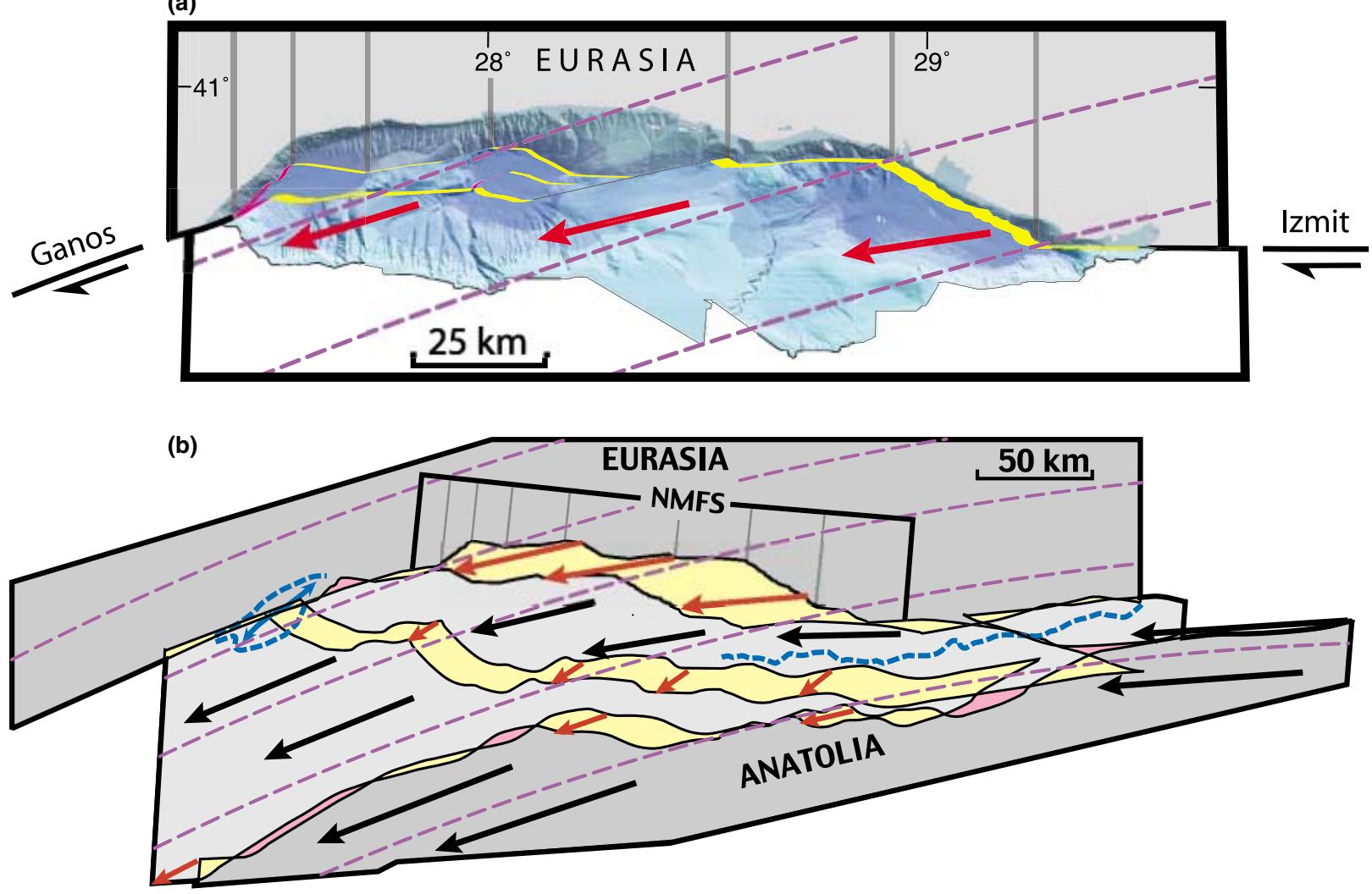

Fig. 5 Kinematic model of the Sea of Marmara pull-apart. (a) Reconstruction of the submarine NMFS in the late Quaternary (last few $10^{5} \mathrm{yr}$ ). The 3.5 -km-offset ridge of Fig. 4 is restored. Overlaps and gaps in the reconstruction (in yellow and pink, respectively) are regions where extension and compression have occurred leading to the present geometry. They emphasize the stepped pullapart geometry. Large normal faulting along the north Cinarcik escarpment $(2 \mathrm{~km}$ extension) and significant thrusting at the Ganos bend ( $0.5 \mathrm{~km}$ contraction) are expected. Red arrows show the direction of motion of the southern block relative to Eurasia. The direction of Anatolia/Eurasia motion deduced from GPS measurements is also shown (purple arcs constructed with Euler pole from McClusky et al., 2000). Vertical grey lines indicate the simplified boundary used in (b). (b) Reconstruction at $\approx 5$ Ma with geological markers (in dashed blue) restored and the corresponding displacement field (slightly modified from Armijo et al., 1999). The Anatolia-Eurasia direction of motion obtained in the previous reconstruction by Armijo et al. (1999) was, within errors, the same as that deduced from GPS (McClusky et al., 2000). To simplify, the Anatolia/Eurasia motion is taken strictly parallel to the GPS model [purple arcs as in (a)]; however, the average Anatolia/Eurasia velocity deduced across Marmara for the past 5 Myr is $17 \mathrm{~mm} \mathrm{yr}^{-1}$, somewhat less than the $22 \pm 3 \mathrm{~mm} \mathrm{yr}^{-1}$ determined using GPS (Kahle et al., 2000). Black vectors are relative to the northern block (Eurasia); red vectors are relative to the adjacent block. Vectors inside the pull-apart deviate from Anatolia/Eurasia circles because reconstruction requires slip partitioning. The Submarine NMFS is indicated by grey lines and the northern frame of A is rotated to its initial position. The reconstruction shows that significant, long-term, oblique extension has occurred over the NMFS. The direction of motion across it (large red arrows, locally referred to Eurasia) is indistinguishable from that of the shorter-term motion determined in (a). This is because the two reconstructions (a) and (b) require primarily right-lateral slip along the Izmit and Ganos faults.

metric slip separation seems to have persisted since the inception of the NAF in the region.

Two overall explanations for slip separation are possible:

1 Slip partitioning is an effect of gravity. Faulting commences with oblique slip on one feature. However, with time the topography created by the dip-slip component creates stresses that resist further opening. The normal component of motion conse- quently migrates to new structures while strike-slip motion persists on the original feature.

2 Slip separation is attributed to asymmetric loading during propagation of the NAF. During a first stage the NAF at depth deviates to the north, instead of propagating further southwestwards along the arc determined by the rotation of Anatolia. This causes oblique extensional features to form, consistent with the NE-dipping normal faults in the southern Sea of Marmara, which may have provided the initial asymmetry to the pull-apart. As the motion propagates to the surface, strike-slip becomes more concentrated on the northern fault system, which has more adapted geometry, rather than on the early normal faults. This system once established then persists as the northern NAF propagates farther southwestward, across the Dardanelles into the Aegean (Armijo et al., 1999). 
The two mechanisms are not mutually exclusive, but for the first, structures should evolve with time. In the absence of clear evidence for such evolution, it is proposed that the asymmetric slip partitioning within the pull-apart is an effect of propagation. A more detailed knowledge of the structure and stratigraphy of the Sea of Marmara, together with information from land studies should allow this scenario to be refined and modelled.

\section{Acknowledgments}

This work is part of the collaborative programme on the seismic risk in the Istanbul and Sea of Marmara region coordinated by the Turkish TUBITAK and the French INSU-CNRS, with support from MTA, IFREMER, the French Ministry of Foreign Affairs (MAE) and the ECHO division of the EC. We are grateful to all the crew of RV Le Suroît. During and after the cruise André Le Bot efficiently processed the bathymetric data. We thank Sara Bazin for processing the seismic data. Gilles Peltzer and Jean-Philippe Avouac are thanked for thorough reviews. AnneClaire Morillon helped substantially drafting the figures. This is Institut de Physique du Globe de Paris (IPGP) paper no. 1799.

\section{References}

Ambraseys, N.N. and Jackson, J.A., 2000. Seismicity of the Sea of Marmara (Turkey) since 1500. Geophys. J. Int., 141, F1-F6.

Armijo, R., Tapponnier, P., Mercier, J.L. and Han Tonglin, 1986. Quaternary extension in southern Tibet: field observations and tectonic implications. J. Geophys. Res., 91, 13,803-13,872.

Armijo, R., Meyer, B., King, G.C.P., Rigo, A. and Papanastassiou, D., 1996.
Quaternary evolution of the Corinth Rift and its implication for the late Cenozoic evolution of the Aegean. Geophys. J. Int., 126, 11-53.

Armijo, R., Meyer, B., Hubert, A. and Barka, A., 1999. Westwards Propagation of the North Anatolian Fault into the Northern Aegean: Timing and kinematics. Geology, 27, 267-270.

Barka, A.A. and Kadinsky-Cade, K., 1988. Strike-slip fault geometry in Turkey and its influence on earthquake activity. Tectonics, 7, 663-684.

Hubert-Ferrari, A., Barka, A., Jacques, E. et al., 2000. Seismic hazard in the Marmara Sea following the 17 August 1999 Izmit earthquake. Nature, 404, 269-272.

Hubert-Ferrari, A., Armijo, R., King, G.C.P., Meyer, B. and Barka, A., 2002a. Morphology, displacement and slip rates along the North Anatolian Fault (Turkey). J. Geophys. Res., in press.

Hubert-Ferrari, A., King, G., Manighetti, I., Armijo, R., Meyer, B. and Tapponnier, P., 2002b. Long-term Elasticity in the Continental Lithosphere; Modelling the Aden Ridge Propagation and the Anatolian Extrusion Process, Geophys. $J$. Int. submitted.

Imren, C., Le Pichon, X., Rangin, C., Demirbag, E., Ecevitoglu, B. and Görür, N., 2001. The North Anatolian fault within the Sea of Marmara: a new evaluation based on multichannel seismic and multibeam data. Earth Planet. Sci. Lett., 186, 143-158.

Kahle, H.G., Cocard, M., Peter, Y. et al., 2000. GPS-derived strainrate field within the boundary zones of the Eurasion, African and Arabian Plates. J. Geophys. Res., 105, 23,353-23,700.

King, G.C.P., Stein, R.S. and Rundle, J.B., 1988. The growth of geological structures by repeated earthquakes. 1. Conceptual framework. J. Geophys. Res., 105, 5695-5719.

Le Pichon, X., Sengör, A.M.C., Demirbag, E. et al., 2001. The active main Marmara fault. Earth Planet. Sci. Lett., 192, 595-616.
McClusky, S., Balassanian, S., Barka, A., et al., 2000. Global Positioning System constraints on the plate kinematics and dynamics in the eastern Mediterranean and Caucasus. J. Geophys. Res., 105, 5695-5719.

Okay, A., Demirbag, E., Kurt, H., Okay, N. and Kuscu, I., 1999. An active, deep marine strike-slip basin along the North Anatolian fault in Turkey. Tectonics, 18, 129-147.

Okay, A.I., Kaslilar-Ozcan, A., Imren, C., Boztepe-Guney, A., Demirbag, E. and Kuscu, I., 2000. Active faults and evolving strike-slip fault basins in the Marmara Sea, northwest Turkey: a multichannel reflection study. Tectonophysics, 321, 189-218.

Parke, J.R., Minshull, T.A., Anderson, G. et al., 1999. Active faults in the Sea of Marmara, western Turkey, imaged by seismic reflection profiles, Terra Nova, 11, 223-227.

Parsons, T., Toda, S., Stein, R.S., Barka, A. and Dieterich, J.H., 2000. Heightened odds of large earthquakes near Istanbul: an interaction-based probability calculation. Science, 288, 661-665.

Sengör, A.M.C., Görür, N. and Saroglu, F., 1985. Strike-slip faulting and related basin formation in zones of tectonic escape: Turkey as a case study. In: StrikeSlip Faulting and Basin Formation (K.T. Biddke and N. Christie-Blick, eds). Spec. Publ. Soc. Econ. Paleont. Miner., Tulsa, 37, 227-264.

Stein, R.S., King, G.C.P. and Rundle, J.B., 1988. The growth of geological structures by repeated earthquakes. 2 . Field examples of continental dip-slip faults. J. Geophys. Res., 95, 13,319-13,331.

Yeats, R.S., Sieh, K. and Allen, C.R., 1997. The Geology of Earthquakes. Oxford University Press, New York.

Received 25 October 2001; revised version accepted 18 December 2001 